\title{
É POSSÍVEL UMA SOCIEDADE SEM CULPA? O LUGAR DA CULPABILIDADE NOS PROCESSOS DE SUBJETIVAÇÃO
}

Fernanda Goldenberg

Diante das transformações ocorridas no processo de transição da modernidade para a contemporaneidade, o presente trabalho questiona o lugar do sentimento de culpa na estrutura social e seu impacto junto às subjetividades. Para tal, são utilizados como referência alguns pensadores da cultura, predominantemente psicanalistas e filósofos, com o intuito de discutir se é a culpa um sentimento imprescindível ou não para o psiquismo humano. Dessa forma, busca-se reunir nesta dissertação diferentes pontos de vista acerca do sentimento de culpa, com o intuito de provocar uma discussão sobre sua relação com a subjetividade contemporânea.

\section{BANCA:}

Carlos Augusto Peixoto Junior (Orientador)

Auterives Maciel Junior

Eduardo Rozenthal

Data da defesa: 06/02/2009 